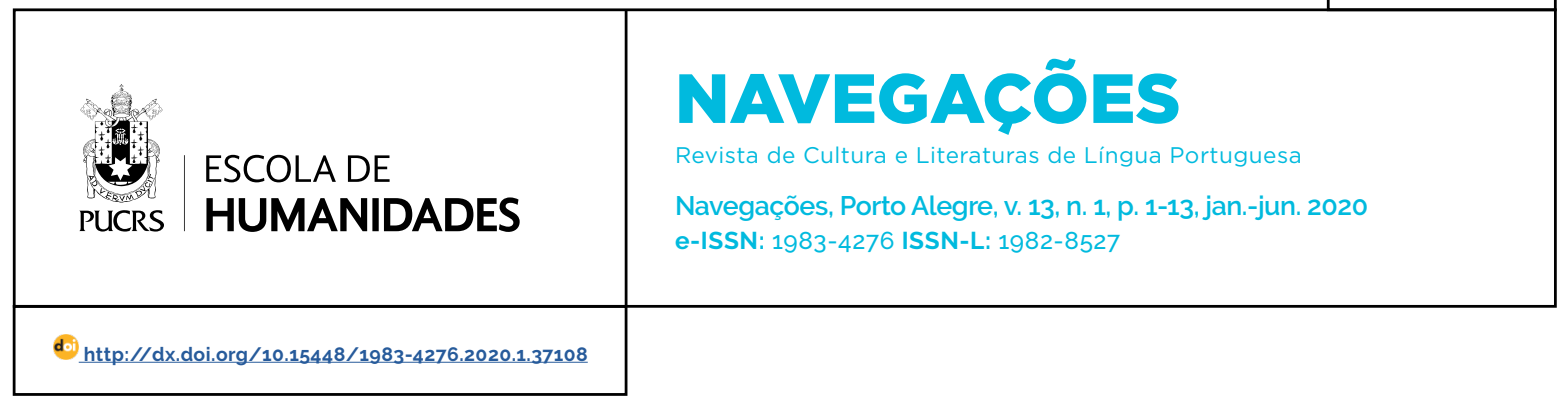

SEÇÃO: ENSAIOS

\title{
Violência doméstica em "Sinhazinha" (1929) de Afrânio Peixoto
}

\author{
Domestic violence in Afrânio Peixoto "Sinhazinha" (1929)
}

\section{Denise Rocha ${ }^{1}$}

orcid.org/0000-0003-3906-2957

rocha.denise57@gmail.com

\section{João Paulo Melo}

Fernandes ${ }^{1}$

orcid.org/0000-0001-8325-9058

jpfernandes@ufc.br

Recebido em: 16 jul. 2019.

Aprovado em: 9 jan. 2020.

Publicado em: 10 ago. 2020
Resumo: O propósito deste artigo é apresentar o panorama da vida conjugal no Brasil durante o século XIX, a partir do contexto da violência doméstica descrita na literatura regionalista do escritor baiano Afrânio Peixoto. Para tanto, serão analisados no romance Sinhazinha (1929) duas das micronarrativas que circundam a trama principal do livro - as histórias de Pia e da "Cabocla do Catulé" cujo tema preocupa-se em descrever as relações de amor e de ódio que estão presentes nos envolvimentos fatais dos personagens. A perspectiva do estudo relaciona-se ao debate sobre o poder do patriarcado, da supremacia masculina e da submissão feminina segundo as reflexões de Gilberto Freyre (2004), Mary del Priore (2009, 2013, 2016) e Raquel Soihet (2017), entre outros

Palavras-chave: Afrânio Peixoto. Feminino. Regionalismo. Romance. Violência doméstica.

Abstract: The purpose of this article is to present the panorama of married life in Brazil during the nineteenth century, from the context of domestic violence described in the regionalist literature of the Bahian writer Afrânio Peixoto. For this purpose, two of the micronarratives that surround the main plot of the book - the stories of Pia and the "Cabocla do Catulé" - will be analyzed in the novel Sinhazinha (1929) - whose theme is concerned with describing the relationships of love and hate that are present in the fatal involvements of the characters. The perspective of the study is related to the debate on the power of patriarchy, male supremacy and female submission according to the reflections of Gilberto Freyre (2004), Mary del Priore (2009, 2013, 2016) and Raquel Soihet (2017), among others. Keywords: Afrânio Peixoto. Female. Regionalism. Romance. Domestic violence.

\section{Introdução}

Ódio e desprezo à condição feminina no Brasil é coisa antiga, ainda que a priori tal temática tenha vindo à baila apenas nos últimos anos, dado a alta reincidência de crimes cometidos por homens ${ }^{2}$ contra mulheres, os quais se iniciam com ameaças e agressões físicas sucessivas cujo desfecho é o assassinato das vítimas. Segundo a Lei n. ${ }^{\mathbf{1 3}} \mathbf{1 0 4}$, de 9 de março de 2015, o que hoje se configura como feminicidio ${ }^{3}$ é uma categoria específica de homicídio cujo teor tanto se atenta à condição da vítima ser do sexo feminino quanto pela circunstância em que esse delito ocorre, caracterizando-se pela: "I - violência doméstica e familiar; II - menosprezo ou discriminação à condição de mulher" (BRASIL, 2015, p. 1). Brasileiro de Segurança Pública de 2018 (cujos dados são referentes ao ano anterior): foram registrados 60.018 estupros, 1.133 feminicídios, 221.238 registros de violência doméstica com lesão corporal dolosa e 4.539 homicídios contra mulheres (FÓRUM BRASILEIRO DE SEGURANÇA PÚBLICA, 2018). Além disso, ainda que misoginia seja a rigor caracterizada pelo desprezo masculino à condição de ser mulher, não se excetua que alguns crimes dessa mesma natureza, ainda que em menor número, sejam também cometidos por mulheres "machistas", as quais carregam consigo essa mesma carga de aversão e/ou ódio internalizado ao mesmo sexo.

O termo "femicidio" ou "feminicidio" (forma mais comumente utilizada na América Latina) aparece pela primeira vez no livro Femicide: The Politics of Woman Killing (1992), escrito por Jill Hadford e Diana E. H. Russell. 
Todavia, nem mesmo o imperativo da legislação parece ser capaz de refrear essa onda de agressões verbais e físicas que culminam em morte, uma vez que sob a herança do regime patriarcal exista ainda uma presunção machista de que a vida da mulher está subordinada à vontade de seu cônjuge. Não à toa, em Feminidios: conceitos, tipos e cenários, Stela N. Meneguel e Ana Paula Portella (2017, p. 3079) indicam que essa misoginia que leva um individuo a agredir e/ou matar sua vítima motivado unicamente pelo fato dessa ser mulher "[...] é parte dos mecanismos de perpetuação da dominação masculina, estando profundamente enraizado na sociedade e na cultura. [...]". Adiante, outro trecho do mesmo artigo esclarece o que está por trás desse desprezo à condição feminina, ao declarar que:

A dominação patriarcal explica a desigualdade de poder que inferioriza e subordina as mulheres aos homens, estimulando o sentimento de posse e controle dos corpos femininos e o uso da violência como punição e mecanismo para mantê-las na situação de subordinação. Assim, os feminicidios são mortes femininas que se dão sob a ordem patriarcal, uma forma de violência sexista que não se refere a fatos isolados, atribuidos a patologias ou ciúmes, mas expressa ódio misógino, desprezo às mulheres e constituem mortes evitáveis, e em grande maioria, anunciadas, já que grande parte representa o final de situações crescentes de violência (MENEGUEL; PORTELLA, 2017, p. 3080).

Também em 'Femicidios' e as mortes de mulheres no Brasil, Wânia Pasinato (2011, p. 230) apresenta semelhante argumento para explicar o motivo desse tipo de mortandade, principalmente quando escreve que: "[...] A violência contra as mulheres é definida como universal e estrutural e fundamenta-se no sistema de dominação patriarcal presente em praticamente todas as sociedades do mundo ocidental [...]".

Com efeito, tais episódios de agressões e assassinatos contra mulheres no espaço privado estão vinculados à retroalimentação de uma supremacia masculina que continua presente na sociedade brasileira, indicando assim o longo caminho a ser percorrido para se tentar minimizar os efeitos dessa misoginia, porquanto se sabe que:

Ainda que algumas dessas mortes [fe-
minicidios] possam ser atribuidas ao
exercicio perverso de poder e domi-
nação dos homens sobre as mulhe-
res, discussões envolvendo as teorias
do patriarcado avançaram nos últimos
anos e algumas levantam a possibili-
dade de que o patriarcado pode não
estar extinto nem estar apresentando
sinais de exaustão, mas seguramente
sofreu transformações para garantir
sua sobrevivência num mundo em
que os papéis sociais de gênero estão
mudando em velocidade vertiginosa
(PASINATO, 2011, p. 237).

Ao longo da história política brasileira, a expressiva quantidade de documentos juridicos que contabilizam esse tipo de violência contra a mulher é proporcional ao descaso com que as autoridades governamentais vêm encarando essa problemática social, pois até a segunda metade do século passado sequer mencionava-se a criação de políticas públicas que vislumbrassem coibir tais crimes, o que igualmente comprova a tolerância do Estado no contexto de uma sociedade regida por homens.

Com base nessas informações, o objetivo deste estudo é fazer um breve levantamento sobre como era a vida conjugal dos brasileiros durante o século XIX, além de perceber como a dinâmica da vida dos casais é representada em Sinhazinha (1929) - romance de Afrânio Peixoto, ${ }^{4}$ que é ambientado nesse mesmo período. Desse modo, é possivel demonstrar a partir da literatura nacional como se exercitava o patriarcado e a supremacia masculina na sua forma mais agressiva através das cenas de violência doméstica que são descritas nessa obra regionalista.

A história de Sinhazinha conta a origem da familia de Clemência, a filha mais nova do Coronel João Batista Pinheiro "Canguçu" e de Dona Emilia Moura, um casal de fazendeiros cujo casamento,

\footnotetext{
4 Júlio Afrânio Peixoto nasceu em Lençóis (BA) em 1876. Foi médico, político, historiador, crítico literário e membro da Academia Brasileira de Letras. No campo da literatura escreveu obras de natureza simbolista, urbana e regionalista como Rosa Mistica - Símbolo Trágico (1900), A Esfinge (1911), Maria Bonita (1914). Fruta do Mato (1920), Bugrinha (1922), As Razões do Coração (1925). Uma Mulher Como as Outras (1928) e Sinhazinha (1929). Faleceu no Rio de Janeiro (RJ), em 1947.
} 
na juventude, havia sido desaprovado por causa da inimizade existente entre ambas as parentelas. Na véspera da Noite de São João, por ocasião da chegada do mascate Juliano de Morais à fazenda Campinho, Clemência apaixona-se pelo belo forasteiro. Mesmo sendo correspondida em seu amor, ela sabe que tal união é impossivel, porquanto está prometida, desde cedo, a se deixar raptar por um primo Moura e casar-se com ele. No entanto, desafiando seu pai e a tradição familiar, a protagonista elabora um plano para poder se casar com Juliano e ao mesmo tempo dar cabo da rivalidade entre os dois clãs.

Em paralelo à trama principal, as histórias contadas pelo personagem Tomé (agregado da fazenda e homem de confiança da família Pinheiro) a Juliano ilustram a vida sertaneja, inclusive registrando casos de violência doméstica (intimidação, agressão verbal e física e assassinato) que são cometidas por personagens masculinos que desprezam e/ou discriminam suas parceiras por causa de sua condição feminina. Em tom de confidência, os crimes passionais cometidos contra as personagens Pia e "Cabocla do Catulé" (epiteto pelo qual é referenciada) casam-se com homens machistas e violentos, de modo que sofrem constantes agressões motivadas por ciúme e desconfiança de um possivel adultério. Como resultado dessas sucessivas cenas de violência doméstica, Pia acaba sendo assassinada brutalmente a facadas por seu cônjuge, enquanto a "Cabocla do Catulé", devido às constantes pressões e ameaças de seu cônjuge, morre à míngua e ao abandono do marido durante o parto de sua primeira filha.

O objetivo deste estudo é apresentar, segundo as reflexões de Gilberto Freyre (2004), Mary del Priore (2009, 2013, 2016) e Raquel Soihet (2017), entre outros, duas cenas de violência doméstica, descritas em Sinhazinha, obra ambientada no século XIX, na trajetória das personagens Pia e "Cabocla do Catulé".

\section{Vida conjugal no Brasil oitocentista}

Ainda que o século XIX seja lembrado como o século do Romantismo, a vida conjugal dos brasileiros, em sua grande maioria, em nada se assemelhava às ficções adocicadas publicadas nos folhetins. Ao contrário do espirito romântico que evocava uma aura de encantamento e fascinio produzidos pela alma feminina, as mulheres deveriam resignar-se à sua condição de submissão e inferioridade mediante a autoridade de seus maridos, a quem prevaleciam todos os direitos e concessões legitimados pelo patriarcado.

Com efeito, o casamento nada mais era do que um acordo entre familias abastadas, não se relacionado especificamente ao amor. Em Ordem Médica e Norma Familiar, Jurandir Freire Costa afirma que:

Os casamentos faziam-se sob a égide das razões ou interesses familiares. Pais, tutores ou outros responsáveis decidiam que alianças seriam contraidas pelos filhos ou tutelados, considerando apenas os benefícios econômicos e sociais do grupo familiar. Os motivos de ordem afetiva raramente pesavam na determinação de uma união conjugal [...]. O casamento não celebrava, portanto, o reconhecimento social de uma união amorosa entre individuos. O amor não era um pressuposto necessário à ligação conjugal. Como, aliás, a atração física, cuja ausência ou presença em nada alterava a composição da aliança. Contrato conjugal era, de fato, um mero relé no intercâmbio de riquezas (COSTA, 1979, p. 215-216).

Neste sentido, o casamento burguês oitocentista espelhava-se na distinção de papeis entre maridos e esposas. É o que declara Gilberto Freyre (2004, p. 208) em Sobrados e Mucambos, ao dizer que: "[...] é característico do regime patriarcal o homem fazer da mulher uma criatura tão diferente dele quanto possível. Ele, o sexo forte, ela o fraco; ele o sexo nobre, ela o belo". Adiante, Freyre menciona que a anatomia do corpo da esposa deveria igualmente contribuir para essa dominação masculina, posto que ela fosse vista como "[...] Uma doente, deformada no corpo para ser a serva do homem e a boneca de carne do marido". Como explicitam Maria Aparecida C. M. Santos e Vera Lúcia R. Salles (2015, p. 130-131) em O corpo em transe: a moral sexual sobre o corpo feminino no Brasil no final do século XIX e início do $X X$, o corpo da mulher estava de tal modo 
associado à lascivia que as instituições religiosas, médicas e civis ocupavam-se em estabelecer normas de conduta que interditassem os impulsos sexuais femininos. Dessa forma, o homem que se deixasse seduzir pelos encantos de uma mulher, seria irremediavelmente levado à ruína.

As teorias científicas que estavam em voga durante o século XIX corroboravam para a inferiorização do sexo feminino. Cesare Lombroso, ${ }^{5}$ por exemplo, dizia que as mulheres eram portadoras de várias deficiências cognitivas, além de possuírem um perfil psicológico dissimulado e pérfido. Em Mulheres pobres e violência no Brasil urbano, Raquel Soihet comenta que:

Ele [Lombroso] afirmava que a mulher era menos inteligente que o homem, explicando que a presença da genialidade nesse sexo, por uma confusão de caracteres sexuais secundários, faria a mulher parecer um homem disfarçado. Era a mulher dotada de menor sensibilidade nos mais diversos âmbitos, especialmente na sexualidade (SOIHET, 2017, p. 381).

Também os estudos de Jean-Martin Charcot ${ }^{6}$ acerca da histeria feminina e da ninfomania revelavam o estado de repressão no qual viviam as mulheres casadas durante o século XIX, porquanto a elas era expressamente negado o direito ao prazer sexual. Sob essa ótica, quaisquer delas que apresentasse sinais de um apetite sexual desordenado ou perverso era vista como um ser diabólico aos olhos da Igreja e da sociedade. Os manuais de medicina dessa época, influenciados pelo higienismo, afirmavam que o sexo era algo a ser praticado com moderação: no bojo dessas recomendações, chegava-se a estipular um tempo ideal para a cópula, a fim de que o casal pudesse ter filhos saudáveis.

No campo religioso, a tradição judaico-cristã trazida ao Brasil através da colonização também reforçava a ideia de que a mulher era um ser inferior ao homem: no Velho Testamento, lê-se que Deus instituiu o casamento (Gênesis 2:23) e o ratificou no Decálogo dado a Moisés (Êxodo 20:14-17); no Novo Testamento, instituindo o casamento monogâmico, o apóstolo São Paulo recomendava que as mulheres cristãs permanecessem submissas aos seus maridos (Efésios 5:22-24). Tal paradigma religioso é o que foi preservado pelo patriarcado, de modo que a indissolubilidade do casamento era uma prerrogativa exclusiva do Direito Canônico. 0 divórcio como possibilidade de resolução para os conflitos conjugais era algo impensado durante a vigência do Código Civil do Império (1822-1889).

Plasmados ao texto de Gilberto Freyre (2004, p. 207-208), todos esses discursos serviram para elaborar um modus operandi de sociedade patriarcal marcado pela "[...] extrema especialização ou diferenciação dos sexos". E como isso se concretizava no cotidiano? Ora, a partir do momento em que se dava "[...] ao homem todas as oportunidades de iniciativa, de ação social, de contatos diversos [...]", enquanto à mulher restaria apenas o acesso "[...] aos serviços e artes domésticas, ao contato com os filhos, a parentela, as amas, as velhas, os escravos. [...]".

Nesse bojo, Raquel Soihet argumenta que essa distinção de papeis já se configurava por si só em uma forma de violência, posto que isso corroborasse com a concepção de que a mulher fosse um ser frágil e incapaz, cuja vida dependeria única e exclusivamente da vontade do homem. Como consequência, tal pensamento tornou-se norma cultural, de modo que:

[...] permaneceriam as mulheres por longo tempo sem poder dispor livremente de seus corpos, de sua sexualidade, violência que se constituiu em fonte de múltiplas outras violências. Quanto aos homens. estimulou-se o livre exercicio de sua sexualidade, simbolo de virilidade; na mulher tal atitude era condenada, cabendo-lhe reprimir todos os desejos e impulsos dessa natureza (SOIHET, 2017, p. 390).

Durante os oitocentos, quer seja nas cidades, quer seja no sertão, as relações conjugais, ainda que conflituosas, obedeciam a uma hierarquia de poder regida pela batuta do marido. Em Histórias 
da Gente Brasileira, Mary del Priore (2016, v. 2, p. 428) declara que a vida amorosa dos casais era assiduamente marcada por arroubos de paixão e de ciúme, de maneira que "Existia um alto nivel de violência nas relações conjugais [...]. Não só violência física, na forma de surras e açoites, mas também a violência do abandono, do desprezo, do malquerer". Nesse mesmo contexto, em Mulheres e Costumes do Brasil de Charles Expilly, descreve-se a penosa situação das mulheres que viviam sob a tutela tirânica de seus cônjuges, assim que:

A desconfiança, a inveja e a opressão resultantes prejudicavam todos os direitos e toda a graça da mulher, que não era, para dizer a verdade, senão a maior escrava do seu lar. Os bordados, os doces, a conversa com as negras, 0 cafuné, o manejo do chicote, e aos domingos uma visita à igreja, eram todas as distrações que o despotismo paternal e a politica conjugal permitiam às moças e às inquietas esposas.

Francamente, a solicitude dos senhores era exageradamente tenebrosa e previdente. Havia mesmo entre eles quem se gabasse de degradar sistematicamente a mulher, condenando-a à ignorância eà reclusão perpétua (EXPILLY, 1935, p. 401-402).

O marido era o senhor da casa, da esposa e dos filhos, de modo que no exercício da sua autoridade ele poderia recorrer à aplicação de castigos e de agressões físicas. Entendida como norma conjugal, tais "corretivos" tanto serviam para reafirmar a posição de inferioridade da mulher quanto para perpetuar a supremacia masculina do patriarcado. Sobre isso, em Minha História das Mulheres, Michelle Perrot (2007, p. 47-48) confirma o discurso que estava em voga durante esse período, transcrevendo que: "[...] 'Quem ama castiga'. Bater na mulher é uma prática tolerada, admitida, desde que não seja excessiva. Se os vizinhos escutam os gritos de uma mulher maltratada, não interferem. 'O homem deve ser o rei em sua casa'".

Neste cenário, era de se esperar que controvérsias conjugais afetassem a harmonia do lar: não eram poucos os casos de esposas que se rebelavam contra o autoritarismo dos maridos, porém, o resultado era desastroso para elas, porquanto eram inúmeras as notícias de maus-tratos contra mulheres que haviam "desacatado" a vontade de seus cônjuges. Em Histórias e Conversas de Mulher, Mary del Priore (2013, p. 33) afirma que havia "[...] mulheres que apanhavam, eram amarradas ao pé da cama ou em cercas fora de casa, deixadas ao relento, sem alimento - enfim, mulheres que sofriam toda forma de violência física".

À medida que crescia o número de desajustes de convivência entre os casais, era de se esperar que também aumentasse o número de processos judiciais reivindicando a anulação do casamento e/ou o divórcio. Geralmente, os motivos desses desentendimentos partiam de uma mera desconfiança do marido acerca da fidelidade da esposa, a qual poderia ser comprovada pelas vias de fato ou não. Como explicita Mary del Priore (2016, v. 1 , p. 343, 352) em Histórias da Gente Brasileira, o homem que se sentisse traido poderia repudiar, expulsar ou mesmo matar a mulher que houvesse cometido adultério. Outra forma de punição, menos usual, seria a reclusão perpétua da esposa em conventos, condicionada ao cônjuge a responsabilidade pela manutenção da enclausurada.

Da parte das mulheres, havia a tentativa de reconciliação conjugal ou de denúncia quanto aos castigos físicos que thes eram infligidos. Infelizmente, tal apelo muitas vezes era ineficaz contra essa supremacia masculina. Em Moralidades brasilicas: deleites sexuais e linguagem erótica na sociedade escravista, Ronaldo Vainfas (1997, p. 271) apresenta um breve relatório do teor dessas ações penais marcadas pela misoginia, ao relatar que as marcas dessa violência doméstica se caracterizavam por "[...] maus-tratos de todo tipo, como se veem nos processos de divórcio e na obsessão das esposas por 'acalmar' seus maridos por meio de magias; mulheres sumariamente assassinadas por mera suspeita de adultério [...]".

Quando na ocorrência de crimes passionais, o marido dificilmente seria condenado por haver matado a esposa adúltera. Como demonstra Mary del Priore (2016, v. 2, p. 401), tal tipo de assassinato se justificava pelo fato de que para o homem patriarcal "Não havia castigo maior do que a pecha de corno, pecha que pairava 
sobre homens públicos casados quando se queria atingi-los na sua probidade". No entanto, é curioso ressaltar que o mesmo não ocorria entre as classes populares, onde a separação de corpos era a saída mais comum. Por fim, havia ainda uma terceira situação, na qual essas esposas confessavam, de fato, haver prevaricado durante o matrimônio, e que só o haviam feito por "fragilidade humana", cansadas pelos maus-tratos e pelo abandono conjugal do marido.

De acordo com a tradição jurídica oriunda do período colonial, o assassinato da esposa adúltera pelo cônjuge era sempre justificável. Em História dos Crimes e da Violência no Brasil, José César Coimbra assinala que:

O entrelaçamento entre legalidade, sexualidade, suspeitas, crime e, eventualmente, morte interroga o Brasil pelo menos desde o século XVII. É isso que se pode ver nas Ordenações Filipinas, código que vigorou entre 1603 e 1830, no que se refere ao direito penal, sendo estendido até 1916, quanto ao direito civel. Ali, o homem traído que assassinasse a mulher adúltera não cometia crime. Nessa legislação, a defesa contra a agressão à honra isentava o homem de punição. No Código Penal de 1890 . o adultério era penalizado apenas se praticado pela mulher. O homem seria considerado adúltero somente se mantivesse concubina teúda e manteúda (COIMBRA, 2017, p. 258).

Entre o final do século XIX e o início do XX crescia assustadoramente o número de crimes passionais motivados pelo adultério feminino. Ademais do que já vinha ocorrendo na vida social, o espirito artístico daquele fin de siècle parecia alimentar ainda mais esse sentimento de "defesa da honra" masculina em detrimento do direito à vida da mulher, uma vez que:

Os crimes beneficiavam-se da onda de romantismo no âmbito da literatura e da arte enfatizando o amor e a paixão. Situações desse teor eram retratadas por Tolstoi, Dostoievski, Daudet, Maupassant e D'Annunzio, cujas obras estão repletas de situações em que o amor e o ciúme aparecem como determinantes dos atos mais impulsivos. A própria vida de alguns desses poetas e romancistas confirmaria a doutrina que aproxima da loucura a paixão pelo amor (SOIHET, 2017, p. 380-381).
Igualmente, não faltavam argumentos científicos que inocentassem o cônjuge mediante esse extremo ato de violência. Segundo Raquel Soihet (2017, p. 380-381), criminalistas clássicos defendiam que durante um "arroubo de paixão" havia uma "[...] suspensão temporária das faculdades mentais [...]", e que na consumação do crime o marido traido perdia temporariamente a "[...] percepção do bem e do mal [...]". Não obstante, além do orgulho ferido do marido que carregasse consigo a pecha de "corno", havia também o sentimento burguês de preservação do patrimônio familiar. Visto por esse ângulo, afirma Soihet: "Os motivos da punição são óbvios, já que o adultério representava os riscos de participação de um bastardo na partilha dos bens e na gestão dos capitais. [...]".

Como foi demonstrado até aqui, vê-se que o patriarcalismo oitocentista, ao mesmo tempo em que dava ao homem a plena liberdade de exercer sua sexualidade dentro e fora do matrimônio, condenava a infidelidade da mulher, que, em geral, era punida com a morte. Nas palavras de Soihet (2017, p. 381), percebe-se que ".... Na prática, reconhecia-se ao homem o direito de dispor da vida da mulher". Todavia, reconhecendo ser o assassinato dessas mulheres o ponto crucial dessa violência doméstica legitimada pelo machismo, não menos graves eram as denúncias de maustratos e agressões fisicas sofridas pelas esposas que ousassem ferir os brios do marido, pois como informa Michelle Perrot (2017, p. 77): "Apanhar e bater era o cotidiano de muitos casais [...]".

\section{Sinhazinha: amor e ódio no sertão baiano}

Escrito durante a estadia de Afrânio Peixoto na França, Sinhazinha foi publicado em 1929, completando ao lado de Maria Bonita (1914), Fruta do Mato (1920) e Bugrinha (1922) uma linha de romances regionalistas ambientados na zona agreste da Bahia. Sucesso editorial como os antecessores, inclusive sendo traduzido para o francês, Sinhazinha difere dos demais por mesclar inventividade e fatos históricos, transpondo à ficção várias cenas de violência que foram registradas nas crônicas de sua terra natal. Ambientado exatamente durante 
o século XIX, o romance é narrado de forma linear e heterodiegética; está estruturado em 27 capitulos e se passa, mais especificamente, na fazenda Campinho, interior de Caetité. ${ }^{7}$

Além da trama principal de viés romântico e das várias cenas de carnificinas ali descritas, a narrativa mostra com vivacidade o panorama sociocultural da região: o cotidiano da vida rural, as festas e as tradições do povo sertanejo (a exemplo da noite de São João, em 24 de junho), a atividade de mascateação etc. Como demonstra Fernando Sales (2001, p. 81) em A Bahia de Afrânio Peixoto, o romance é também um resgate da memória do País, uma vez que conta um dos vários exemplos de desavenças familiares existentes no sertão do Brasil, como as dos Montes e Feitosas (Ceará), dos Lisos e Cabeludos (Alagoas) e a dos Militões e Guerreiros (Bahia). Ademais, é interessante ressaltar que a pesquisa realizada por Afrânio para a composição do livro acaba por remontar a origem familiar do famoso poeta Castro Alves, cuja tia Pórcia Moura é o pivô histórico que dá início a briga que envolve os dois clãs em Sinhazinha. Contudo, aparte da crítica e do êxito de vendas, revelava Afrânio Peixoto (1947, v. VII, p. 307) que a recepção do romance gerou polêmica, principalmente por parte dos descendentes da familia Moura, inconformados com a suposta parcialidade com que o autor havia tratado os Pinheiros "Canguçus".

\subsection{Pia: da calúnia à beatificação de uma mulher}

A história de Pia está descrita no capítulo XXII de Sinhazinha, ocasião na qual Tomé está regressando à fazenda Campinho na companhia de Juliano. Durante o trajeto, o sertanejo interrompe seu caminho para reverenciar um cruzeiro que havia sido posto à beira da estrada. Curioso, Juliano deseja saber o porquê da atenção dada àquele memorial e Tomé explica que a cruz marca o local onde havia morrido uma santa aos olhos do povo, uma mulher da vila de Pedras que havia sido assassinada pelo marido ciumento.

No entanto, o que chama atenção do leitor é que ao invés de contar a história de Pia, Tomé começa o seu relato a partir da vida pregressa de João Itapicuru (mais conhecido como João Canoeiro), o marido assassino. Como esclarece a narrativa, João era dono de boa reputação, porquanto era "Amigo certo, esforçado, serviçal, tinha bom nome entre os camaradas e os patrões. Um braço forte, uma boa disposição para o trabalho, e bonito, e ganhador da vida... Por isso tudo, as mulheres gostavam dele [...]" (PEIXOTO, 1976, p. 130).

Neste momento, perceba-se que o discurso de Tomé (um homem de mentalidade patriarcal) exalta a honra de João Canoeiro, justificando que nenhum dos seus atos poderiam desaboná-lo aos olhos daquela sociedade rural. Outro ponto interessante da fala do sertanejo-narrador e que reforça a concepção de supremacia masculina, é que a vida de Pia é entendida como uma sombra que só passa a ter importância a partir do momento em que ela entra na vida de seu futuro marido.

O trecho abaixo apresenta uma descrição da beleza arrebatadora de Pia, demonstrando que a moça possuía vários pretendentes que disputavam sua atenção:

Um dia, num arraial, perto daqui, nas
Pedras, uma moça bonita [Pia], de boa
gente, começou a chamar a atenção
e um bando de rapazes a quiseram
por mulher. Chegava-se a dar volta
no caminho, para dar com os olhos
nela. Tinha um sorriso branco que nem
água de cachoeira... E que olhos, moço!
Cobriam a gente com a sua proteção...
Comparando mal, pareciam o pálio do
Santíssimo na procissão do Bom Jesus...
(PEIXOTO, 1976, p. 131).

Contudo, os vários registros sobre a história da vida social no Brasil demonstram que essa beleza apenas serviria para desgraçar a vida da moça, caso ela viesse a se casar. É o que revela Mary del Priore em Histórias da Gente Brasileira, quando diz que:

A mulher muito bonita despertava desconfiança, pois podia incentivar desejo de outros homens e a temidas traição. A quadrinha sertaneja aconselhava: 'Bezerro de vaca preta/onça pintada não come/quem casa com mulher feia/ não tem medo de outro home' (PRIORE, 2016, v. 2, p. 428).

\footnotetext{
Municipio situado a 645 quilômetros de Salvador.
} 
Não obstante, ainda que o encantamento produzido por Pia despertasse o desejo de muitos pretendentes, seus olhos estavam postos apenas em João Canoeiro. O trecho a seguir descreve que:

- A rapaziada toda queria casar; ela [Pia] dava a trela a todo o mundo, bulia com este, com aquele, muito dada, muito maneira. Mas não lhe falassem a sério. Repelia logo, e dizia: 'Só me caso com João Itapicuru, mas para endireitar aquele coração... Aquele não conheceu ainda mulher' [...] (PEIXOTO, 1976, p. 131-132).

Em um discurso de tom misógino, lê-se que Tomé rebaixa a condição feminina de Pia ao afirmar que ela "dava a trela a todo o mundo". Mesmo sendo uma mulher desimpedida, o fato dela não guardar seu recato acabaria por tornála ré de julgamento da sociedade patriarcal em que estava inserida. Como explicita Raquel Soihet (2017, p; 387), as solteiras que optassem por uma vida livre "[...] eram mulheres perdidas, indignas, perigosas por servirem de descaminho para as 'filhas de familia de poucos teres', incapazes de sentimentos mais nobres".

Além disso, em meio a tantos assédios, um homem em especial (alcunhado como "caboclo") acabaria por conspirar contra a vida de Pia. Abaixo, Tomé relata que:

Houve um, o desgraçado de um caboclo, que se tomou de paixão pela moça, fez todos os papéis, ofereceu dinheiro aos pais, deu-lhe vestidos e presentes, mas não conseguiu nada. Então não se sabe como, esse maldito se pôs a ser amigo de João, a ter negócios com ele, emprestando dinheiro, assistindo-o nas doenças, tomando as dores e a defesa do rapaz. Por fim, aconselhou a ele que se casasse, já era tempo, considerado gente boa, só lhe faltava pôr decência na vida... Casasse com a Pia, nenhuma mais bonita do que ela, boa família e, depois, gostava dele, queria endireitar-lhe o coração... João sorriu, assuntou, mas não disse nada (PEIXOTO, 1976, p. 132).

Na citação acima, lê-se que esse caboclo, inconformado em ser preterido por Pia, decide se vingar. Veja-se que outra vez o depoimento do sertanejo-narrador traz à tona o poder da supremacia masculina do patriarcado. A ideia de fazer mal à rapariga parte de uma atitude tomada por ela que fez com que o caboclo, como homem, se sentisse diminuido ou desafiado. A recusa de Pia em ceder ao seu intento passa a gerar nele um menosprezo que viria a resultar na premeditação de um crime de ódio.

Elaborando um plano de vingança, o caboclo trata de aproximar João Canoeiro de Pia, porquanto sabia que ela estava interessada no mancebo. No entanto, sem se dar conta de que suas atitudes estavam sendo observadas pelo pretendente, a rapariga permanecia despreocupada quanto à guarda de seu recato. Dessa maneira, quando ocorre uma festa da vila de Pedras, descreve-se que Pia:

Dançou com quantos quis, recebeu flo-
res deste e daquele, cantou em desafio
com três e quatro. João ficou doido...
No dia seguinte, pedia a Pia em ca-
samento, que levou uns tempos sem
responder, até que os pais acabaram
com ela, aceitando. Ela queria, estava
visto, mas, com João, só assim, porque,
senão, arisco bateria asas, e ia-se em-
bora. Pia não mudou de vida, continuou
a rir e a dançar, coitadinha, pensando
que assim prendia o noivo. João, de
fato, estava cada vez mais embeiçado
(PEIXOTO, 1976, p. 132).

Diferente do que deveria se esperar de uma moça do sertão, o comportamento de Pia é escandaloso: como explicita o trecho acima, os flertes eram constantes, de modo que ela aceitava flores de outros homens e formava diversos pares para dança. Além disso, a narrativa afirma que mesmo com o compromisso de casarse com João Canoeiro, Pia não se retirou da vida pública, sempre com a intenção de manter viva a chama do interesse de seu noivo.

Entretanto, tão logo ocorre o casamento, as núpcias do casal tornam-se uma noite de tormenta: possesso de ciúme, João Canoeiro age de forma violenta para com Pia, exigindolhe explicações quanto ao seu comportamento desrespeitador durante o noivado. Entretanto, a narração de Tomé mostra que tudo não passava de um jogo de intriga do caboclo para destruir a vida da moça, assim que:

Um dia, passa o vigário pelas Pedras, em desobriga, e João casou... Houve festa e, à noitinha, foram para a casa 
que o rapaz edificara, perto das Pedras Apaixonado casou, mas os ciúmes que lhe botaram na alma tinham produzido o efeito. Era o malvado do caboclo, que the abria o olho, dando suspeita. João, na noite de casamento, pôs a mulher em confissão, para que contasse o que tinha feito com Fulano e Sicrano, e Sancho e Martinho. Eram as intrigas do outro, do falso amigo, o maldito, o preterido, que se vingava desse jeito... A pobrezinha não tinha outra coisa que dizer, senão que rira, dançara, cantara, recebera flores e presentes, e isto ele sabia e não havia mal. Mas João queria saber tudo, tudo o que the contaram, e que ela não sabia... Aos gritos da moça, acudiu um vizinho que bateu na porta, e, enquanto João abria, a pobre moça fugiu pelos fundos, ganhando mato, até a casa dos pais (PEIXOTO, 1976, p. 132-133).

O trecho acima reconstitui o cenário de violência doméstica em Sinhazinha, uma vez que tal agressão é cometida pelo cônjuge no interior da casa em que passariam a coabitar. Ademais, vê-se que a hostilidade de João Canoeiro está associada a uma ideia de posse sobre a vida da esposa. Não havendo forma de se defender, só restava a Pia fugir da presença do marido a fim de preservar sua vida. Assim, lê-se que ela "fugiu pelos fundos, ganhando mato, até a casa dos pais" (PEIXOTO, 1976, p. 133).

Como informa Britto Lemos (1946, p. 175) em O Crime e os Criminosos na Literatura, a atitude de João Canoeiro só poderia ser explicada a partir de uma ótica patriarcal, porquanto "No sertão, o marido e o pai invocam êsse poder. A idéia da propriedade é contemporânea da de domínio da mulher no cérebro dêsses indivíduos". Igualmente, em Minha História das Mulheres, Michelle Perrot confirma que era essa a atitude esperada pelo marido de Pia, porquanto a mulher no século XIX:

[...] pode receber 'corretivos', como uma criança indócil, pelo chefe da casa, depositário da ordem doméstica. 'Quem ama castiga'. Bater na mulher é uma prática tolerada, admitida, desde que não seja excessiva. Se os vizinhos escutam os gritos de uma mulher maltratada, não interferem. 'O homem deve ser o rei em sua casa' (PERROT, 2017, p. 47-48).

Atemorizada pelo que poderia the passar, Pia acaba por retornar à casa de seus pais. Nesse caso, percebe-se a relevância que tem o peso da opinião pública para a absolvição da rapariga. Tal situação é comentada por Mary del Priore em Histórias da Gente Brasileira 1, quando ela afirma que "Há registros de mulheres que fogem de seus cônjuges, voltam para a casa dos pais, tentam refazer suas vidas. Quem julgava os comportamentos, apoiando um ou outro lado do casal, era a comunidade" (PRIORE, 2016, p. 352).

Assim, o relato de Tomé está em conformidade com a declaração de Priore ao descrever que:

A voz pública porém foi por ela [Pia]. Os rapazes acusados foram os primeiros a jurar a inocência das relações com a rapariga. Todos quiseram casar, mas ela os desprezara a todos, só pensando em João. - 'Bem feito, estava agora tendo o pago!' Toda a gente trabalhou nas pazes, João mandou pedir perdão e, com o sim dela, foi buscá-la para a casa... Agora é que se ia consumar o casamento [...] (PEIXOTO, 1976, p. 133).

Não obstante, ainda que tudo parecesse indicar a reconciliação do casal, a história finalmente chega ao seu trágico clímax: ao se deparar com marido e esposa regressando a casa, o caboclo novamente semeia a dúvida no coração de João Canoeiro. Conforme detalha a narrativa, lê-se que:

Quando vêm das Pedras, aqui, neste lugar, encontram o malvado do falso amigo lo caboclo] que vinha em sentido contrário, de propósito fazendo-se encontrado.

- 'Você, João, um rapaz honrado, ainda com esta mulher?!... Fulano e Sicrano vão se rir de você... Você vai aproveitar o sobejo deles... Ninguém mais the apertará a mão' (PEIXOTO, 1976, p. 133).

Como resultado da provocação do caboclo, João Canoeiro tem um assomo de cólera acaba assassinando a própria esposa a facadas, por não admitir que Pia pudesse "macular" sua honra de homem patriarcal, pois: "[...] parou, e sem saber o que fazer. Vingar a mulher, ou vingar-se a si. Quando a reação veio, tonto de raiva e de paixão quis da pobre uma confissão e, como não a obtivesse, o ciúme fez isto... matou-a, a punhaladas..." (PEIXOTO, 1976, p. 133). Nesse contexto, como explicita Raquel Sohiet, vê-se que: 
[...] os homens pobres encontravam nas mulheres um abrigo seguro em face dos dissabores da existência, marcada pelo desemprego ou pelos parcos ganhos. Não conseguiam, porém, desfrutar uma relação mais igualitária com suas companheiras, já que sobre eles incidiam o estereótipo dominante de que a mulher era sua propriedade privada sobre a qual tinha um poder ilimitado. A insegurança e a frustração decorrentes da impossibilidade de exercer concretamente o papel que lhes era prescrito exacerbavam sua agressividade (SOIHET, 2017, p. 380).

O resultado dessa violência marcada por exacerbada tragicidade traz ainda à tona uma verdade inusitada acerca de Pia, bem como mostra a punição do caboclo e do marido homicida, pois, conforme as palavras de Tomé, sabe-se que:

As últimas palavras dela foram estas: - 'Eu te perdôo... Morro pura como nasci...'Ali foi enterrada: João foi preso e acabou na cadeia de Caitité, héctico, o cabelo crescido, a barba crescida, como um monstro arrependido... O desgraçado do tal amigo, apontado pela voz do povo, como o autor de tudo, não teve mais ninguém que dele quisesse saber... Não the vendiam os vendeiros, não the davam água as casas do caminho, ninguém tinha com ele relação, caiu no desprezo, e ficou doido, e está recolhido na cadeia de Caetité, onde encontrou ainda o outro, cuja desgraça causou [...] (PEIXOTO, 1976, p. 133).

Apesar do final desalentador, o discurso de Tomé possui um tom moralizador: ao declarar que morria "pura como nasceu", Pia é redimida de suas atitudes escandalosas, porquanto se comprovava que ela jamais havia se entregado a outro homem. Por outro lado, ainda que o caboclo quisesse produzir ciúme em João Canoeiro, a atitude de Pia é vista como superior, porquanto ela não apenas perdoa o seu algoz como ainda revela que sempre permaneceu virgem, cumprindo assim com a determinação social imposta às mulheres pelo patriarcado.

Esse mesmo discurso moralizante tanto exalta a guarda do recato como uma virtude a ser cultivada pelas mulheres quanto passa a enaltecer a figura de Pia como um modelo vivo de comportamento feminino a ser seguido.
Tamanha é a comoção causada por sua morte que ela se torna uma santa de devoção popular. É o que Tomé afirma ao dizer que:

Quem passa por aqui reza um pai-nosso e uma ave-maria, põe uma pedra na sepultura da mártir e umas flores. Tenho visto velas acesas... Já the fazem promessas. Uma pobre mãe já vi trazer o filhinho aqui, com malinas, pedindo para o sarar. Vem gente de longe, fazer romaria. E quando se fala dela, da pobre Pia, aqui, dez léguas ao redor, ninguém se priva de dizer:

- Uma santa! Deus the fale n'alma.. (PEIXOTO, 1976, p. 133-134).

Com efeito, o percurso narrativo de Pia vai de um extremo a outro: a jovem emancipada e risonha, apresentada inicialmente como alvo de galanteios e pivô de ciúmes, torna-se, após a morte, uma "mártir" beatificada pelo povo sertanejo tão somente pela manutenção da sua virgindade bem como pela fidelidade ao marido, reforçando a concepção de que as mulheres deveriam manterse submissas à supremacia masculina.

\section{2 "Cabocla do Catulé": mulher desprezada e abandonada pelo marido}

No capítulo XXIII de Sinhazinha, Tomé também conta a história de sua falecida esposa, cabocla do Catulé, com quem teve uma única filha. Semelhante ao ocorrido com Pia, esta personagem é vítima de maus tratos no contexto de uma abusiva relação conjugal: além de padecer com o ciúme do marido que a julga tê-lo traído, ela é abandonada durante a sua primeira gestação, vindo a falecer por ocasião do parto.

Entretanto, a primeira menção à cabocla da Catulé é feita ainda no capítulo VIII, quando Juliano, o mascate, faz uma sugestiva indagação a Tomé. Nesse momento, o jovem comerciante aproveita a ocasião para perguntar ao sertanejo:

- Tomé, como é que a gente faz quando está apaixonado?..

O tabaréu coçou a barba rala, sob o queixo.

- Não sei por mim, porque a gente quando está assim está fora de si e não sabe senão de sua querência. Mas sei pelo que vejo nos outros... Xodó se 
conhece logo; é como tosse, não se pode disfarçar. Tenho prática. Um dia eu contarei a vosmincê minha vida... Gostei de uma mulher la cabocla do Catulé], que morreu por mim, e de quem duvidei. Castiguei-me, amarrando o coração dai por diante. Não quis e não quero saber de rabo-de-saia. Ninguém me viu mais assuntar nelas. É como se não existissem (PEIXOTO, 1976, p. 56-57).

Não divergindo da narrativa de Pia, o relato sobre a cabocla do Catulé possui os mesmos elementos argumentativos - uma disputa amorosa entre dois homens pelo amor da mesma mulher, além do ciúme do cônjuge para com a esposa, cujas consequências são desastrosas. Abaixo, Tomé argumenta a Juliano que:

O caso foi que eu ganhei o feitiço de uma cabocla, lá para as bandas do Catulé. Não somente eu, ai é que foi o mal, um bando de gente. Um, porém, era meu rival, e parecia o favorecido. Quando apareciamos os dois, era para ele que ela ria. O ciúme foi me fazendo uma gastura. Um dia, o meu companheiro anoiteceu, não amanheceu; desertou, sumiu. Eu então me adiantei, fui recebido, o casamento se decidiu. Casei, mas a mulher continuou a rir, às vezes, para os outros, e o ciúme me cresceu... (PEIXOTO, 1976, p. 135).

Adiante, o leitor tem conhecimento de que além da presença de um rival, Tomé alegava ter motivos para desconfiar de sua mulher, porquanto era rapariga risonha e sedutora para com os homens, não conservando a tradição patriarcal da guarda de seu recato. Exatamente por causa desse desafio da cabocla às convenções sociais, é que Tomé afirma que:

Tive muitas vezes vontade de esganá-la, para obrigar a confessar o que eu queria. Contudo, eu tinha até medo de dizer o que pensava, mesmo para perguntar, para tirar a limpo... Por fim, não pude mais, não podia ficar naquela incerteza mortal. Mortal para ela e para mim. Decidi fazer uma viagem. la procurar o meu antigo rival e, com ele, tiraria a prova. Andei por aí, à procura dele, sem achar: 'esteve aqui', 'foi para tal parte', 'anda pelas bandas do Brejo Grande'... 'não esquenta lugar', 'andejo como só ele'... Era o que eu ouvia, por toda a parte onde o procurava, sem achar. Sempre me diziam: 'esteve aqui, foi-se embora'. Perdi meses, nesta quizilia (PEIXOTO, 1976, p. 135).
Como demonstra o trecho supracitado, tal narrativa é contada exclusivamente pela ótica de Tomé, de modo que todo o texto está eivado das impressões pessoais do sertanejo (um homem patriarcal). Veja-se que em relação ao suposto rival, ele afirma que aquele "parecia [ser] o favorecido", e que quando se apresentavam "era para êle [o rival] que ela [a cabocla] ria". Dessa maneira, vê-se que isso apenas contribuia para aumentar o ciúme do marido, o qual pensava estar sendo traido.

Preocupado em preservar sua honra, a desconfiança de Tomé torna-se uma espécie de paranoia, reconhecendo, inclusive, que por várias vezes pensou em agredir a cabocla para que confessasse o que ele queria ouvir. Nesse contexto, vê-se que suas atitudes se assemelham ao ocorrido com João Canoeiro, no relato sobre Pia. Atormentado pelo fantasma da desconfiança, o sertanejo não se convencia que a esposa lhe era fiel, chegando até mesmo a abandoná-la durante a gravidez.

Em sua obstinação, Tomé parte pelos sertões, desejoso de vingar-se do rival. Inesperadamente, eis que surge a oportunidade de reencontrar-se com seu oponente, pois:

Um dia, no Orobó, no encalço dele, estou aboletado no mercado, alta noite, quando ouço, perto, uma voz. Era a dele! Não imagina, moço, a minha alegria: quase me denuncio. Apalpei o cabo do punhal. No meu desespero já não precisava tirar a limpo: era acabar com o caso. Mas eram dois homens, conversavam, e eu assuntei. Um contava ao outro suas viagens, de déu em déu, sem poder ficar em lugar nenhum, já fazia meses. Estava pra adoecer. Não sabia o que seria dêle. Um dia, o achariam morto, na estrada. O outro perspicaz, mostrando-se amigo, quis saber e consolar. (PEIXOTO, 1976, p. 135).

Nessa ocasião, Tomé finalmente se dá conta de que a cabocla sempre the havia sido fiel, principalmente, quando o sertanejo acaba ouvindo a confissão dos lábios do próprio rival, dizendo:

- Eu me enganei. Pensei que ela gostava de mim, fiz fôrça nesta ilusão. Quando pedi [a cabocla], em casamento, me disse, que tirasse dai o juizo, não pensasse nisto, pois gostava de um outro [Tomé], um amigo, um bom sujeito, que não tinha coragem de olhar para ela... 
Insisti, mas não consegui nada. Anoiteci, não amanheci. Andei por aí. Quis voltar. Mas soube que o meu amigo tomou coragem, pediu, e logrou; casaram-se e são felizes. Que faço eu mais no mundo? Empatar a felicidade dos outros? Dar o espetáculo de minha desgraça? Ando de déu em déu, sem saber o que faça... Se vosmincê encontrar a Morte por aí, diga-lhe que ando à procura dela... (PEIXOTO, 1976, p. 136)

Desejoso de pedir perdão à cabocla, Tomé retorna imediatamente para casa. Entrementes, a alegria do sertanejo é interrompida pela fatalidade - após retornar da viagem, não houve tempo para que se reconciliassem, pois ela havia falecido durante o parto de sua primeira filha. Eis a sua fala:

Ouvi, ouvi, pensei morrer de alegria; chorei de arrependimento, pensando no pensamento mau com que insultei a minha mulher, e até, - por que não dizer? - com pena do desgraçado!... Não me descobri e, de madrugada, bem cedo, pus os pés no caminho de casa...

Tomé fêz uma pausa. Abaixou a vista, como que turva. E, a voz comovida continuou:

- O castigo de Deus me esperava... Minha mulher tinha tido o seu mau-sucesso, desgosto de minha ausência, sem se saber aonde; morrera de parto, estava enterrada... Uma filhinha fora recolhida em casa de seu Coronel João Batista, onde a defunta viera pedir abrigo, e foi Sinhazinha quem tomou conta dela... Mais do que ela, a criatura inocente, meu ciúme matara a mãe, da maneira mais fria, parecendo ingratidão... Na minha raiva, porém, de mim mesmo, nem queria ver a pequena [...] (PEIXOTO, 1976, p. 136).

Ainda que a narrativa não descreva indícios de agressões fisicas, a violência doméstica de Tomé contra a cabocla se faz notar pelo tom agressivo com que o sertanejo relata a história de seu relacionamento. Ele a abandona, grávida, sem sequer informar em quais condições ele a deixou, tanto que o texto diz, em seguida, que em seu regresso a esposa já estava morta e que a "filhinha fôra recolhida em casa de 'seu' Coronel João Batista, onde a defunta viera pedir abrigo, e foi Sinhàzinha quem tomou conta dela".

Outrossim, conjectura-se através do texto que a cabocla do Catulé deve ter sido vítima de ameaças e intimidações que abalaram sua saúde psíquica, pois conforme descreve o relato de Tomé a esposa infeliz havia padecido de "mau-sucesso" e de "desgôsto", e que, por fim, "morrera de parto". Ademais, ainda que seu depoimento tenha um tom de remorso, seu discurso aponta a mulher como um ser não apenas capaz de enfeitiçar, mas que é também causador de desgraças e desilusões. Não à toa, sua experiência argumenta que foi justamente por causa de uma mulher (a cabocla do Catulé) que sua vida se desgraçou.

A marca dessa violência misógina cometida por Tomé se reflete em sua própria confissão e arrependimento, já que acaba reconhecendo o mal que causou à esposa e à filha, assumindo a responsabilidade pela morte da primeira e a orfandade da segunda, pois como ele mesmo assegura: "Mais do que ela [a esposa], a criatura inocente [a filha], meu ciúme matara a mãe, da maneira mais fria, parecendo ingratidão" (PEIXOTO, 1976, p. 136).

\section{Considerações finais}

Os trágicos episódios passados pelas mulheres do sertão da Bahia, Pia e a "Cabocla do Catulé", refletem casos de violência doméstica, que até hoje são perpetuados na sociedade patriarcal brasileira. Ambos devem ser compreendidos, segundo Gilberto Freyre, como o quadro da supremacia masculina que está consolidada na tradição de subjugar a mulher: "Ele, o sexo forte, ela o fraco; ele o sexo nobre, ela o belo" (FREYRE, 2004, p. 208).

Refletindo sobre as palavras de Freyre, vê-se que Pia foi vitima de assassinato praticado pelo esposo ciumento, enquanto a "Cabocla do Catulé" tornou-se, também, vitima da pressão psicológica praticada pelo cônjuge, que a abandonou à mingua, quando estava ainda gestante.

Tal panorama de opressão descrito em Sinhazinha, a qual é ambientada no Brasil do século XIX, demonstra que a dinâmica da violência doméstica praticada pelo homem contra a mulher não mudou muito na contemporaneidade. Tanto que para coibir essa prática machista foi promulgada a Lei n. ${ }^{\circ} \mathbf{1 3 . 1 0 4}$, de 9 de março 
de 2015, que caracteriza o delito feminicídio, como uma espécie de homicídio categorizado pela condição da vítima ser do sexo feminino e, por isso, sofrer violência doméstica e familiar, devido ao menosprezo sentido pelo homem que discrimina e pune a mulher por ser mulher.

\section{Referências}

A BÍBLIA DA MULHER: leitura, devocional, estudo. Edição de Sidney Alan Leite. Trad. de Neyd V. Siqueira, prepar. e adapt. de texto por Liege Maruci e Luciana Abud; revisão de Érica S. S. de Freitas et al. Barueri, SP: Sociedade Bíblica do Brasil; São Paulo: Mundo Cristão, 2003. https://doi.org/10.29381/01038559/20182803342-4

BRASIL. Lei № 13.104, de 9 de março de 2015. 2018. Disponivel em: http://www.planalto.gov.br/ccivil_03/_ato2015-2018/2015/lei/L13104.htm. Acesso em: 01 out. 2019

BRITTO, Lemos. O Crime e os Criminosos na Literatura. Rio de Janeiro: José Olympio, 1946.

CAMPOS, Carmen Hein de. Feminicidio no Brasil: uma análise crítico-feminista. Sistema Penal \& Violência, Porto Alegre, v. 7, n. 1, p.103-115, 2015 Disponivel em: http://revistaseletronicas.pucrs.br/ ojs/index.php/sistemapenaleviolencia/article/ view/20275. Acesso em: 01 out. 2019. https://doi. org/10.15448/2177-6784.2015.1.20275

COIMBRA, José César. Até que a morte nos separe In: PRIORE, Mary del; MÜLLER, Angélica. História dos Crimes e da Violência no Brasil. São Paulo: UNESP, 2017. Cap. 9. p. 255-284.

COSTA, Jurandir Freire. Ordem Médica e Norma Familiar. São Paulo: Graal, 1979.

EXPILLY, Charles. Mulheres e costumes do Brasil. Belo Horizonte, Rio de Janeiro: Itatiaia, 2000.

FREYRE, Gilberto. Sobrados e Mucambos. 15. ed São Paulo: Editora Global, 2004.

MENEGUEL, Stela Nazareth; PORTELLA, Ana Paula Feminícidios: conceitos, tipos e cenários. Ciência \& Saúde Coletiva, Rio de Janeiro: v. 22, n. 9, p. 30773086, set. 2017. Disponivel em: https://lume.ufrgs br/handle/10183/169598. Acesso em: 01 out. 2019 https://doi.org/10.1590/1413-81232017229.11412017

PASINATO, Wânia. 'Femicidios' e as mortes de mulheres no Brasil. Cadernos Pagu, Campinas: v. 37. p. 219-246, dez. 2011. Disponivel em: http:// www.scielo.br/scielo.php?script=sci_arttext\&pid $=$ S0104-83332011000200008. Acesso em: 01 out. 2019. https://doi.org/10.1590/s010483332011000200008

PEIXOTO, Afrânio. Sinhazinha. 7. ed. São Paulo: Clube do Livro, 1976.

PERROT, Michele. Minha História das Mulheres.Trad de Angela M. S. Côrrea. São Paulo: Contexto, 2007.
PRIORE, Mary del. Histórias da Gente Brasileira: Império. São Paulo: Leya, 2016, v. 2.

PRIORE, Mary del. Histórias e Conversas de Mulher. São Paulo: Planeta, 2013

PRIORE, Mary del. Matar para não morrer: A morte de Euclides da Cunha e noite sem fim de Dilermando de Assis. Rio de Janeiro: Objetiva, 2009.

SANTOS, Maria Aparecida C. M.; SALES, Vera Lúcia R. O corpo em transe: a moral sexual sobre o corpo feminino no Brasil no final do século XIX e início do XX. Revista Estação Literária, Londrina, v. 13, p. 120-132, jan. 2015.

SOIHET, Rachel. Mulheres pobres e violência no Brasil urbano. In: PRIORE, Mary del; PINSKY, Carla Bassanezi. História das Mulheres no Brasil. 10. ed São Paulo: Contexto, 2017. p. 362-400. https://doi. org/10.4000/clio.210

VAINFAS, Ronaldo. Moralidades brasilicas: deleites sexuais e linguagem erótica na sociedade escravista. In: SOUZA, Laura de Mello e (org.). História da Vida Privada no Brasil. 6. ed. São Paulo: Companhia das Letras, 1997. v. 5. p. 221-274. https://doi. org/10.2166g/tomo.voio.4918

\section{Endereço para correspondência}

Denise Rocha/João Paulo Melo Fernandes

Universidade Federal do Ceará

Avenida da Universidade, 2683, Prédio de literatura, térreo

Campus do Benfica, Área 1, 60020-180

Fortaleza, CE, Brasil 